\title{
Less rain, more water in ponds: a remote sensing study of the dynamics of surface waters from 1950 to present in pastoral Sahel (Gourma region, Mali)
}

\author{
J. Gardelle, P. Hiernaux, L. Kergoat, and M. Grippa \\ Centre d'Etudes Spatiales de la BIOsphère (CESBIO), UMR 5126, UPS-CNRS-CNES-IRD, 18 avenue, Edouard Belin, \\ b.p.i. 2801, 31401 Toulouse Cedex 9, France
}

Received: 23 June 2009 - Published in Hydrol. Earth Syst. Sci. Discuss.: 21 July 2009

Revised: 19 January 2010 - Accepted: 19 January 2010 - Published: 16 February 2010

\begin{abstract}
Changes in the flooded area of ponds in the Gourma region from 1950 to present are studied by remote sensing, in the general context of the current multi-decennial Sahel drought. The seasonal and interannual variations of the areas covered by surface water are assessed using multidate and multi-sensor satellite images (SPOT, FORMOSAT, LANDSAT-MSS, -TM, and -ETM, CORONA, and MODIS) and aerial photographs (IGN). Water body classification is adapted to each type of spectral resolution, with or without a middle-infrared band, and each spatial resolution, using linear unmixing for mixed pixels of MODIS data. The high-frequency MODIS data document the seasonal cycle of flooded areas, with an abrupt rise early in wet season and a progressive decrease in the dry season. They also provide a base to study the inter-annual variability of the flooded areas, with sharp contrasts between dry years such as 2004 (low and early maximal area) and wetter years such as 2001 and 2002 (respectively high and late maximal area).The highest flooded area reached annually greatly depends on the volume, intensity and timing of rain events. However, the overall reduction by $20 \%$ of annual rains during the last 40 years is concomitant with an apparently paradoxical large increase in the area of surface water, starting from the 1970's and accelerating in the mid 1980's. Spectacular for the two study cases of Agoufou and Ebang Mallam, for which time series covering the 1954 to present period exist, this increase is also diagnosed at the regional scale from LANDSAT data spanning 1972-2007. It reaches 108\% between September 1975 and 2002 for 91 ponds identified in central Gourma. Ponds with turbid waters and no aquatic vegetation are mostly re-
\end{abstract}

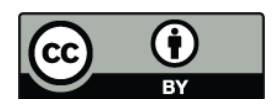

Correspondence to: P. Hiernaux (pierre.hiernaux@cesbio.cnes.fr) sponsible for this increase, more pronounced in the centre and north of the study zone. Possible causes of the differential changes in flooded areas are discussed in relation with the specifics in topography, soil texture and vegetation cover over the watersheds that feed each of the ponds. Changes in rain pattern and in ponds sedimentation are ruled out, and the impact of changes in land use, limited in the area, is found secondary, as opposed to what has often been advocated for in southern Sahel. Instead, major responsibility is attributed to increased runoff triggered by the lasting impact of the 1970-1980's droughts on the vegetation and on the runoff system over the shallow soils prevailing over a third of the landscape.

\section{Introduction}

The Sahel experienced an important decrease in precipitation during the second half of the 20th century, with severe droughts in 1972-1973 and again in 1983-1984 that have had a dramatic impact on the ecosystem and on the population living on the natural resources of this region (e.g. Dregne and Chou, 1992; Olsson, 1993; Hiernaux, 1996; Nicholson, 2001). Yet, in some part of the Sahel, the rainfall deficit did not lead to a decrease in surface runoff or in water-table level, as it happened in the wetter Soudanian and Guinean zones further south in West Africa (Descroix et al., 2009). Indeed, evidence of an increase in water-table level has been reported in endorheic areas, such as in south-western Niger (Leduc et al., 2001). Along the same line, Mahé et al. (2003, 2005a) outlined changes in hydrologic regime of rivers located in Burkina Faso, Mali and Niger, showing a discharge increase north of the 700-mm isohyets, and therefore, over northern

Published by Copernicus Publications on behalf of the European Geosciences Union. 
Soudanian and southern Sahelian zones (see also the review by Descroix et al., 2009, and reference therein). Moreover, field observations in central and northern Sahel in Mali (Ag Mahmoud, 1992; Hiernaux, unpublished data) suggest that, after the major droughts of the 1970's and 1980's, the flood of some temporary ponds extended longer over the dry season or even that some of these ponds became permanent. In southern Sahel, near Niamey (Niger), the increase in areas cleared for cropping, following the demographic expansion of rural population was suggested as a possible explanation for this phenomenon often referred to as the "Sahelian paradox": less precipitation leading to increase in runoff and water table recharge (Leblanc et al., 2008; Favreau et al., 2009). However, similar clearing to expand the area cropped also occurred in the Soudanian zone, without producing an increase in runoff (Descroix et al., 2009). Moreover, this explanation does not hold for pastoral areas in central or northern Sahel, where cropping has a very limited extent. The extent to which the Sahelian paradox applies to central and northern Sahel is still an open question. Yet, assessing and monitoring the recent changes in water resources, and understanding the processes of these changes are critical for the economy and livelihood of the Sahel population. Unfortunately, quantitative information on rainfall, surface water, aquifers and land use is relatively scarce over this wide inland region.

The aim of this work is to document and discuss the evolution of surface water bodies from the mid twentieth century onwards in the pastoral region of Gourma, in Mali. More precisely, the study focuses on the evolution of the flooded area of ponds over the 1954-2007 period. Given the scarcity of in-situ quantitative information, flood regimes are studied through series of remotely sensed data. This requires combining remote sensing information acquired by different sensors and different support, satellite and aerial, to establish a coherent picture of the evolution of the flooded areas. In particular, the average size of the flooded ponds (at most a few hectares in the dry season) requires the use of high resolution data, which is hardly compatible with a suitable timesampling. Indeed, the flooded area of ponds strongly varies with time within a year (seasonal cycle) and display significant year-to-year variability in responses to rainfall variations. To date, attempts have been made to map the pond floods and to estimate flooded areas either at one date, at a relatively high spatial resolution on the basis of one LANDSAT or SPOT-HRV image (Liebe et al., 2005; Lacaux et al., 2007) or at a lower resolution using time series of NOAAAVHRR, SPOT-VGT or MODIS data (e.g. Gond et al., 2004; Haas et al., 2009; Verdin et al., 1996). Beside, the spectral response of surface water has received relatively little attention so far in this region, with a few exceptions like Lacaux et al. (2007). Combined to restrictions in sampling over time, the difficulty of using series of images with different resolutions and different spectral bands probably explains why no monitoring has been carried out so far, despite surface water being such a critical resource in the Sahel.

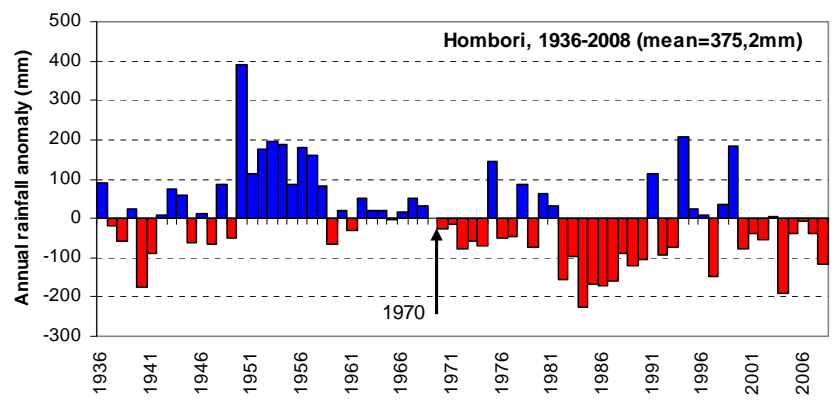

Fig. 1. Deviation of annual rainfall from the 1936-2008 average in Hombori (Mali), data by courtesy of DNM.

After a short description of the site's characteristics and the available data sets in Sect. 2, classification methodologies used to outline the extent of the flooded areas of ponds are presented in Sect. 3 as well as an assessment of the classifiers' accuracy. Section 4 provides an analysis of the flooded area of ponds, which changes over time and space are characterized. Finally, the observed changes of in pond's flood, in the mode of runoff in the Gourma region and their possible causes are discussed in Sect. 5.

\section{Study area and data}

\subsection{The study site}

The Gourma region is located in Eastern Mali, within the loop of the Niger River, down to the border with BurkinaFaso. It extends over the Sahelian bioclimatic gradient from $550-\mathrm{mm}$ annual rainfall, in the south, to $150 \mathrm{~mm}$ in the north. Most of the ponds monitored in this study are located in the centre of the Gourma region, within the study site, referred as "supersite", of the AMMA project (15.58-15.13 $\mathrm{N} ; 1.75$ $1.33^{\circ} \mathrm{W}$ ) with mean annual rainfall ranging between 300 and $450 \mathrm{~mm}$ (Mougin et al., 2009). As elsewhere in the Sahel, the climate is tropical semi-arid with monsoonal rains falling between late June and mid September followed by a long dry season (Frappart et al., 2009). Rainfall recorded at Hombori display the general pattern of the Sahel drought with a sharp contrast between the 1950's and the 1980's (Fig. 1). Indeed, rainfall of most years from 1970 onwards stand below the 1936-2008 average $(375.2 \mathrm{~mm} \pm 110.8)$ with average rainfall dropping by $20 \%$ from $422.2 \mathrm{~mm}$ prior 1970 to $336.2 \mathrm{~mm}$ since. Mean air temperature recorded at Hombori is $30.2^{\circ} \mathrm{C}$. The highest monthly value is observed in May $\left(42^{\circ} \mathrm{C}\right)$ whereas the lowest one is found in January $\left(17.1^{\circ} \mathrm{C}\right)$.

The Gourma region is part of large sedimentary basin which bedrock is mainly composed of Precambrian sandstones and schists eroded in a peneplain only surmounted by a few hard sandstone plateaus. The eroded slopes are locally capped by an iron pan inherited from humid periods of the late Eocene and the Holocene, while a bit more than 


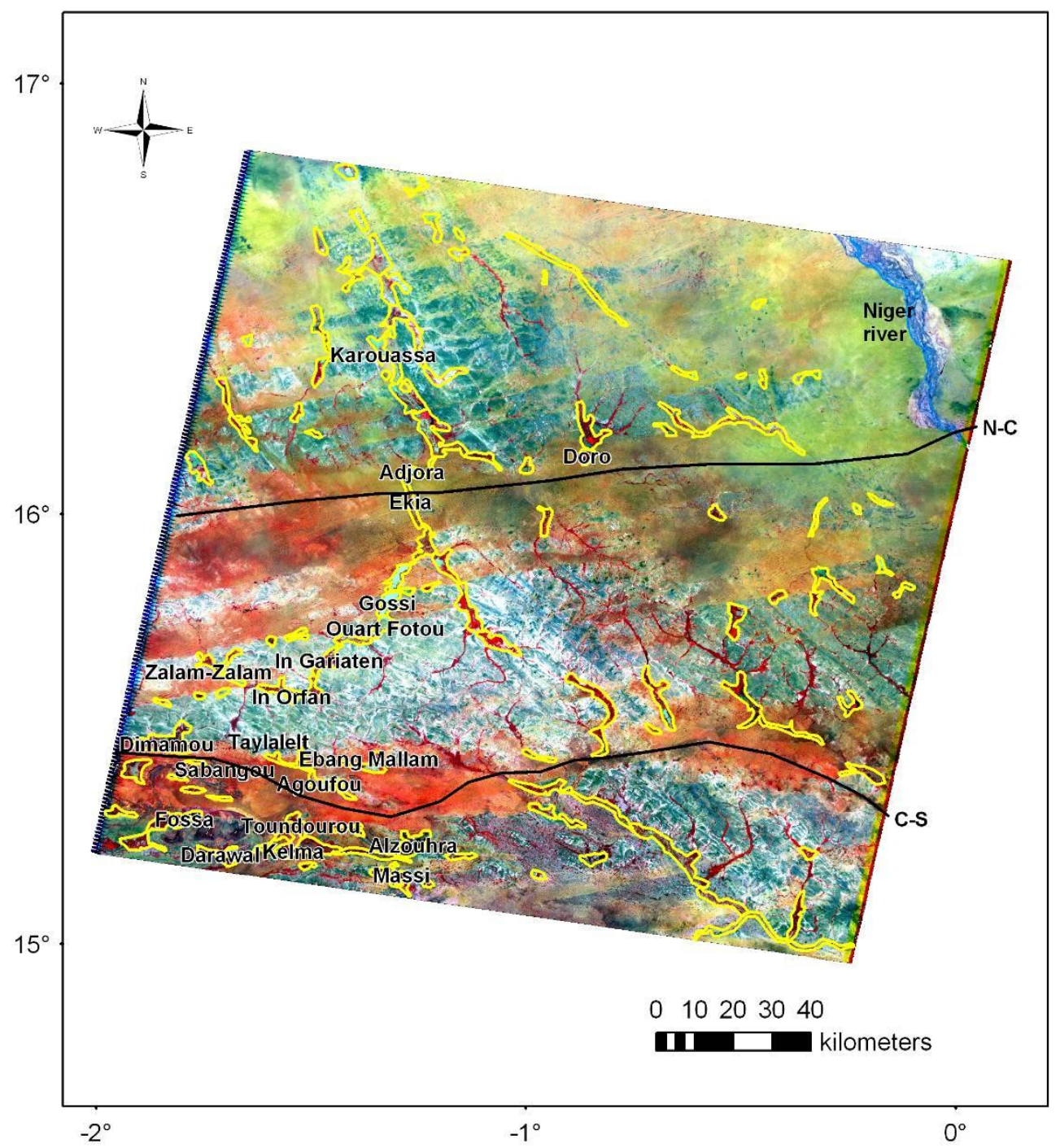

Fig. 2. LANDSAT ETM scene of the Gourma, with contours (yellow) delimiting areas where ponds are found (ponds are actually smaller than these contours). The scene is subdivided into three regions (separated by the C-S and N-C black lines), where ponds show different evolution with time (see text). Only the ponds explicitly mentioned in the text are labelled.

half of the landscape is covered by fixed sand dunes inherited from the arid periods of the Holocene. In valleys, a web of alluvial and lacustrine plains is also inherited from the humid periods, and has been segmented by the sand dunes cutting across valleys. The Gourma region is globally endorheic, but it harbours two runoff systems arranged in a mosaic as shown by the subset represented by the LANDSAT image in Fig. 2. On the sandy soils (58\% of the area, appearing in red-brown-green on the LANDSAT scene in Fig. 2), the endorheic system operates at short distance with limited sheet runoff from dune slopes to inter-dune depressions feeding ephemeral puddles not considered in this study. On the shallow soils associated to rock and iron pan outcrops (30\% of the area, appearing in blue-white in Fig. 2), and on low-land fine-textured soils (12\% of the area, appear- ing in dark red-brown in Fig. 2), the endorheic system operates over much larger distances with concentrated runoff feeding a structured web of rills ending in one or several interconnected ponds, which flood is the object of the study (contoured in yellow on the LANDSAT scene in Fig. 2). The position of the pond along the stream web, its geomorphology and flood dynamics distinguish different categories $(\mathrm{Ag}$ Mahmoud, 1992). Upstream, there are small ponds generated by a local obstacle to the water runoff, such as a bar of hard rock or a sand dune. There are a few case of partially artificial ponds that man historically deepened by digging, the extracted material being deposited in a crescent shaped dam to the downstream side (Taylalelt ponds for example, see Fig. 2). Ponds also occur along the main valleys when the stream bed gets locally deeper, often at the confluence 
of streams (Ekia, Zalam-zalam, In Gariaten), or because of a slow down of the stream flow due to a physical obstacle, either rocky (Massi, Toundourou) or sandy (Gossi, Adjora). Attempts to control the out-flow of these two last ponds have been made by building concrete weirs at the downstream outlet in 2006, their impact on the pond flood is not commented in this paper. Down stream, final ponds are either located at the bottom of the alluvial or lacustrine plain (Kelma, Fossa, Alzouhra), or else at the foot of a natural dam most often due to sand dunes cutting across the valley (Agoufou, Dimamou, Doro). In the first case, pond are often surrounded by temporarily flooded alluvial plain which loamy clay soils are partially colonised by open forest of adapted tree species such as Acacia seyal (Kelma, In Orfan) Acacia nilotica (Ouart Fotou) or Anogeissus leiocarpus (Darawal). Following local perception and nomenclature (Ag Mahmoud, 1992), these temporarily flooded plains are not considered as ponds defined by a minimum water depth of $50 \mathrm{~cm}$ with drying up occurring before October, and thus, they are not included in this study. The flooded areas of the studied ponds vary from a few hectares to a few thousand hectares. Most of these ponds are temporary flooded, but there are a few permanent lakes such as Gossi, and more recently Agoufou, Ebang Mallam and Dimamou. Some of these ponds or lakes also feed local shallow water tables that complement the water resources for the Gourma population and their livestock in a region otherwise deprived of continuous aquifer (Défossez, 1962).

The vegetation of the Gourma region is typical Sahelian with an herbaceous layer almost exclusively composed of annual plants, among which grasses dominate, and scattered bushes, shrubs and low trees (Boudet et al., 1971; Boudet, 1977; Hiernaux et al., 2009a). Almost continuous on sandy soils, except for a few deflation patches and bare dune crests, the herbaceous layer is highly discontinuous on shallow soils and clay plains, living large area bare of vegetation prone to runoff. The density and canopy cover of woody populations are low in average (Hiernaux et al., 2009b). However, there are concentrations of woody plants along drainage lines, around ponds, in the inter-dune depressions and also on shallow soils, with a regular pattern of narrow linear thickets set perpendicular to the slope known as "tiger bush" (Leprun, 1992; Hiernaux and Gerard, 1999). These thickets live on the water and nutrients harvested on the impluvium made by the bare soil upstream, and their development efficiently limit runoff further downstream (d'Herbes et al., 1997). The economy of rural population is mostly pastoral, with various livestock management practices and seasonal mobility strategies (Boudet et al., 1971). In the southern half of the Gourma region, up to the surroundings of the Hombori mountains, husbandry is associated to some staple crops, mostly millet on sandy soils, and sorghum on finer textured soils. Yet, total land cropped in southern Gourma extends on less than $3 \%$ of the land (Cheula, 2009) and has not much expanded since the early 1970's (Marie and Marie, 1974) and 1980's (Bourn and Wint, 1985).

\subsection{Data}

Different types of images, with different spectral, temporal and spatial resolutions, have been employed to monitor the flooded area of ponds over the longest possible period. Before the era of multi-spectral data acquisition with sensors onboard satellites (the first LANDSAT satellite was launched in 1972), images were acquired with airborne cameras or space-borne panchromatic sensors. Series of images from LANDSAT, SPOT, FORMOSAT, CORONA, MODIS have been collected over the Gourma region as well as aerial photograph, as shown on Fig. 3, and detailed in Table 1. Two ponds, Agoufou and Ebang Mallam, are the two main "case studies" with intensive acquisition of high resolution data. Spatial extension over the central Gourma is obtained from less frequent high resolution satellite data: the full LANDSAT archive was searched for images matching approximately with the peak of the pond's flood, resulting in two time series, the September time series consisting of images in 1975, 2001, 2002 and 2007, and the November time series consisting of 1972, 1984, 1986, 1999, 2002 and 2006. The September series offers the largest overlapping area, whereas the November series spans the longest time period.

The temporal resolution of the images is a major issue to study the long term dynamics of the pond's flood. Indeed, the flood of ponds is highly seasonal in the Sahel, therefore to study interannual changes it is crucial to acquire images at same periods of the seasonal cycle. This seasonal cycle should be typically monitored with images every week, or at least every other week. Unfortunately, satellites with a daily or weekly repeat-pass have a coarser spectral resolution than those with 30-days frequency transit, and a compromise has to be found between temporal and spatial resolutions. The coarser resolution among the sets of data used in this study is of $250 \mathrm{~m}$ for MODIS images. The smallest flooded pond that could be classified with these images should have at least 25-ha area. All the other images employed have a spatial resolution finer than $30 \mathrm{~m}$ (Table 1), allowing thereby mapping smaller flooded areas, down to 1 ha. Also, the spectral resolution, namely the ability of the sensor to differentiate bands in different wavelengths, widely varies from one sensor to another, the presence of a middle infrared channel being determinant to accurately classify pond waters partially covered by aquatic vegetation.

SPOT, LANDSAT and FORMOSAT images were already registered in the UTM zone 30 North projection using the WGS84 datum, whereas MODIS images (MOD09Q1, 250$\mathrm{m}$ resolution NIR and red reflectance) were projected in sinusoidal projection. All satellite data have been radiometrically corrected, but neither atmospheric nor viewing angles effects have been taken into account. The CORONA and aerial photographs have been registered only locally, namely around a specific pond, using a registered SPOT-4 panchromatic image with a $5 \mathrm{~m} \times 5 \mathrm{~m}$ pixel size from 2005 as the reference. To this end, tie points, mostly located on trees or rocky features, 
Table 1. Characteristics of the satellite and aerial images used in the study.

\begin{tabular}{llllllc}
\hline Satellite & Sensor & Spatial resolution & Spectral resolution & Year of acquisition & Ground coverage & Number of images \\
\hline SPOT 1 & HRV & $20 \mathrm{~m}$ & G, R, NIR & 1990 & $60 \mathrm{~km} \times 60 \mathrm{~km}$ & 2 \\
SPOT 4 & HRVIR & $20 \mathrm{~m}$ & G, R, NIR, MIR & $2005-2006$ & $60 \mathrm{~km} \times 60 \mathrm{~km}$ & $14+5$ \\
FORMOSAT-2 & $8 \mathrm{~m}$ & B, G, R, NIR & 2007 & $24 \mathrm{~km} \times 24 \mathrm{~km}$ & 30 \\
& MSS & $57 \mathrm{~m} / 60 \mathrm{~m}$ & G, R, NIR & $1972,1975,1984$ & & 3 \\
LANDSAT & TM & $8.5 \mathrm{~m} / 30 \mathrm{~m}$ & B, G, R, NIR MIR & $1986,2006,2007$ & $170 \mathrm{~km} \times 180 \mathrm{~km}$ & 2 \\
& ETM & $28.5 \mathrm{~m} / 30 \mathrm{~m}$ & B, G, R, NIR, MIR & $1999,2001,2002$ & & 5 \\
Terra & MODIS & $250 \mathrm{~m}$ & R, NIR & $2000-2008$ & $1200 \mathrm{~km} \times 1200 \mathrm{~km}$ & 366 \\
CORONA & KH-4A & $2.79 \mathrm{~m}$ & PAN & 1965 and 1966 & $17 \mathrm{~km} \times 230 \mathrm{~km}$ & 8 \\
Aerial photographs & $1.06 \mathrm{~m}$ & PAN & 1954 and 1996 & $10 \mathrm{~km} \times 10 \mathrm{~km}$ & 2 \\
\hline
\end{tabular}
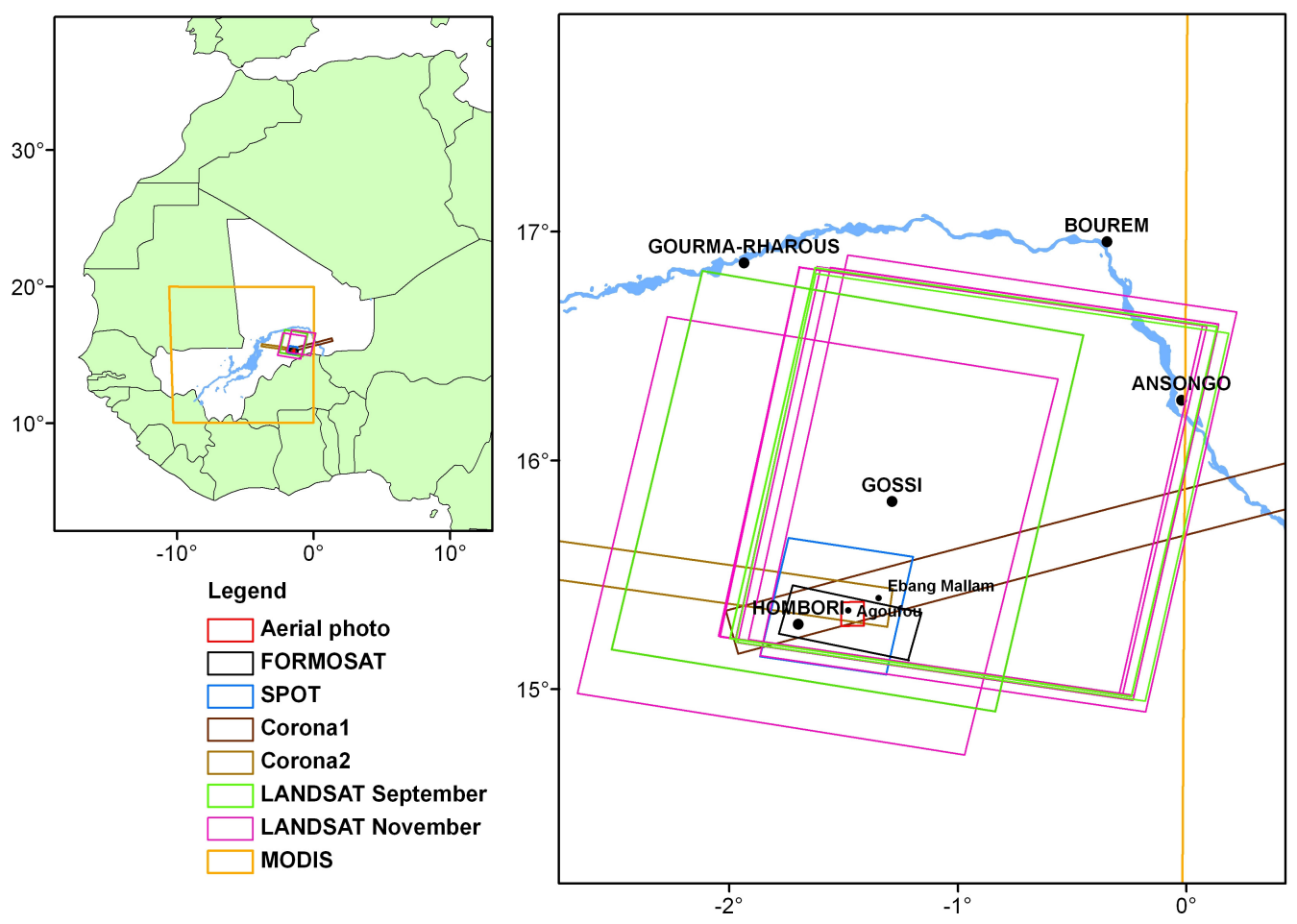

Fig. 3. Study site and frames of the different satellite and aerial images used to monitor ponds in the Gourma (Mali).

have been used and a second degree polynomial transformation has been applied to each image.

Historical climate data (daily rainfall, minimum and maximum temperature) for Hombori have been kindly provided by the national meteorological service (DNM). In addition, a web of manual and automatic rain gauges, and a set of automatic meteorological stations have been deployed in the Gourma progressively since the inception of the AMMA project (Mougin et al., 2009; Frappart et al., 2009).

\section{Methods}

Since the spatial and spectral resolutions of the available satellite images are very heterogeneous, it has not been possible to use the same classification algorithm for all images. Instead, a specific methodology had to be defined for each kind of data sets. Except for LANDSAT images, for which a supervised classification has been applied, all other images have undergone classifications using thresholds on pixels' reflectance or index values. Table 2 summarizes the indexes 
Table 2. Definitions of indexes, based on reflectance values in specific wavelengths. NIR stands for near infrared, MIR for middle infra-red.

\begin{tabular}{|c|c|c|c|c|c|}
\hline Normalized Differ & tation Index & Normalized Differe & idity Index & Normalized Differe & nd Index \\
\hline $\mathrm{NDVI}=\frac{\rho_{\text {nir }}-\rho_{\text {red }}}{\rho_{\text {nir }}+\rho_{\text {red }}}$ & (1) & $\mathrm{NDTI}=\frac{\rho_{\text {red }}-\rho_{\text {green }}}{\rho_{\text {red }}+\rho_{\text {green }}}$ & (2) & $\mathrm{NDPI}=\frac{\rho_{\text {mir }}-\rho_{\text {green }}}{\rho_{\text {mir }}+\rho_{\text {green }}}$ & (3) \\
\hline
\end{tabular}

used for the classifications. The Normalized Difference Vegetation Index (referred to as NDVI, Eq. 1 in Table 2), introduced by Rouse et al. (1973), is classically used to monitor the amount of vegetation. Puech (1994) used it to detect water bodies, and especially ponds with suspended sediment load. However, it is not suitable for separating terrestrial vegetation from aquatic vegetation. That is why Lacaux et al. (2007) have defined the Normalized Differenced Pond Index (NDPI, Eq.3 in Table 2), based on the very low reflectance (about 15\%) of water in the middle infrared wavelength. A Normalized Difference Turbidity Index (NDTI, Eq. 2 in Table 2) has also been used by these authors to evaluate the level of turbidity of open water. It takes heed of the fact that turbid water tends to respond spectrally like bare soil, with low reflectance in the green wavelength, but high in the red one.

\subsection{Spectral signatures of sahelian ponds}

As suggested by Lacaux et al. (2007) for the ponds of the Ferlo region (Senegal), ponds in the Gourma can be sorted into 2 categories, showing a distinct spectral signature. In the following, these two types of flooded ponds are labelled according to the colour in which they appear on a classical Red-Green-Blue false colour composite of Near InfraredRed-Green spectral bands:

1. "blue" ponds, (Fig. 4a), have very turbid water, free of vegetation, with a low reflectance in the middle infrared wavelength. Flood in blue ponds can easily be detected because of the strong negative values of NDPI. Their spectral signature is invariant, whether during the rainy or dry season;

2. "red" ponds, (Fig. 4b), have less turbid water, at least partially covered with various aquatic plants, with high reflectance in the near infrared wavelength as well as high values of NDVI. Their spectral responses are therefore very similar to that of vegetation, which makes them more difficult to identify. Reflectances in the middle infrared are not as low as for the flooded "blue" ponds because of partial vegetation cover over the water surface, which reduce the wave absorption. Aquatic vegetation includes dense aquatic savannas dominated by sedges such as Scirpus maritimus, or grasses such as Oriza barthii, O. longistaminata, Echinochloa stagnina, Panicum subalbidum, that all spread in shallow water at the edge of the pools or on islands. In deeper ponds aquatic vegetation is often limited to patches of plants that are rooted in the mud of the pond bed but have specialised organs such as floating stems (Nelsonia canescens), or leaves (Nymplea lotus, N. maculata, Eichhornia natans), dissected leaves that remain photosynthetically active under a few centimetres of water (Ottelia ulvifolia, Najas pectinata, Rhamphycarpa fistulosa) and a few floating species (Nymphoides indica, Utricularia stellaris, Azolla pinnata), (Boudouresque, 1995). In addition to herbaceous aquatic plants temporary, flooded ponds can harbour some woody plants from species standing seasonal flood such as Ziziphus mauritiana, Acacia nilotica and Mitragyna inermis. After the first rains, the "red" ponds behave as "blue" ponds and turn "red" as aquatic vegetation develops later in the rainy season.

These different spectral signatures have been accounted for in the classification process described for each sensor in the following subsections.

\subsection{Classification of SPOT-4 images (HR-VIR sensor)}

The reflectance value for 'blue' ponds is very low in the middle infrared wavelength, and the NDPI index is markedly negative. SPOT-4 imaging, with its middle infrared channel and its high spatial resolution is therefore very convenient to map the flood for this category of pond. As suggested by Lacaux et al. (2007), the classification of ponds was performed, using a decision tree, using a first threshold on the NDPI value and a second one on the reflectance in the middle infrared wavelength. To determine thresholds values automatically, a region of interest was defined in the centre of the flooded pond to be outlined. The average values of the NDPI and the MIR band within this region were then computed, and a tolerance was applied to those values to define the thresholds used for the classification (namely \pm 0.1 for the index values and $\pm 5 \%$ for the reflectance values).

\subsection{Classification of FORMOSAT images}

FORMOSAT images do not have a MIR band. Alternative classification algorithm is thus needed to outline ponds. A threshold on the NDVI was first applied, using a decision tree, then a threshold on the green band and finally one on the NDTI. These thresholds were computed for each image and for each pond individually in a similar way as for SPOT4 images, that is to say by computing an average value (for 
a)
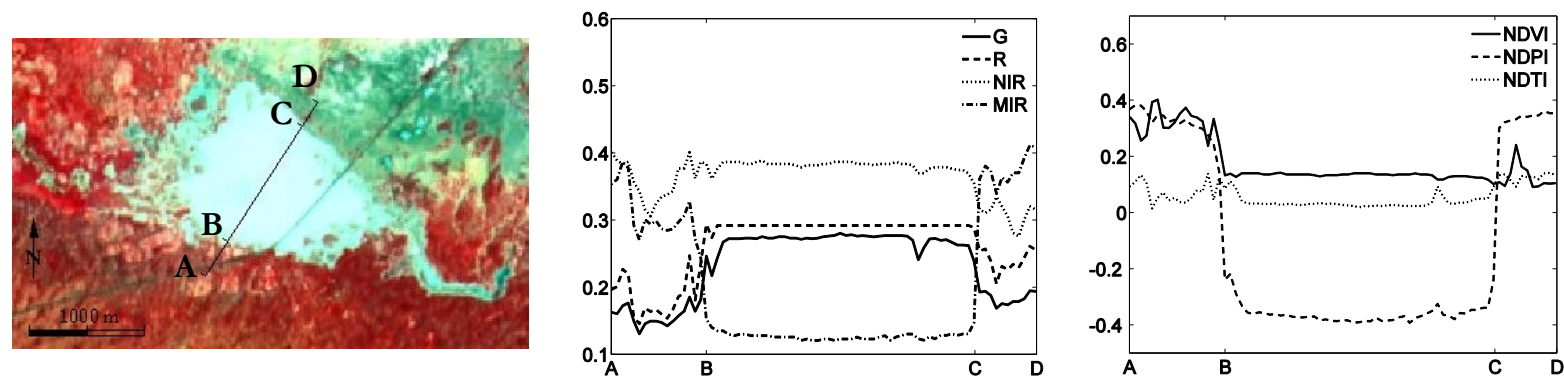

b)
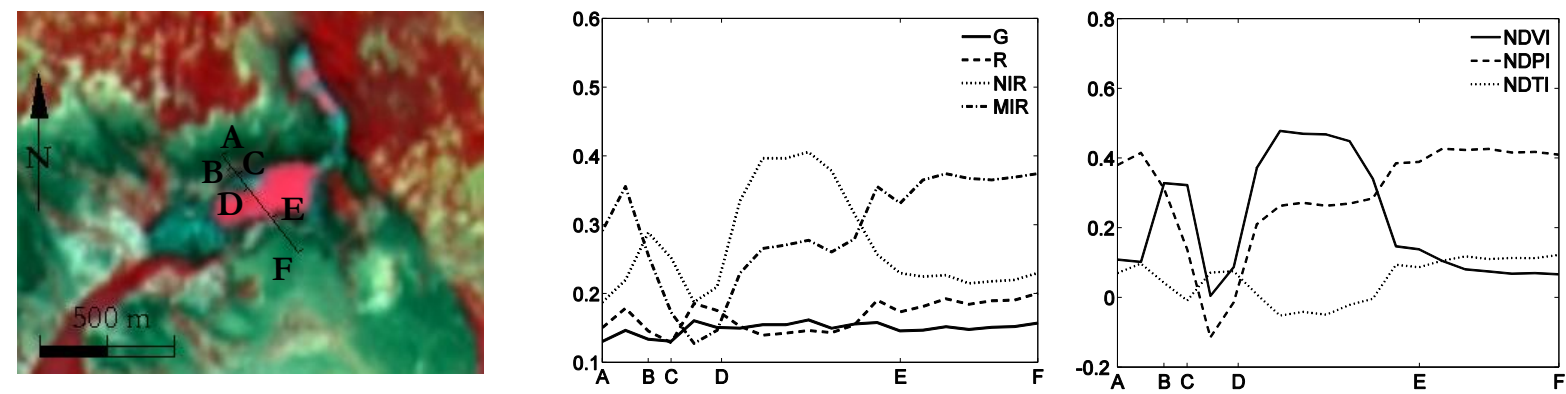

Fig. 4. From left to right, color composite, radiometric transects and corresponding indexes values for the two categories of ponds, based on a SPOT-4 image from 22 August 2005. (a) Agoufou, "blue" pond, turbid water without aquatic vegetation. A-B=vegetation on sand, B$\mathrm{C}=$ open water, $\mathrm{C}-\mathrm{D}=$ rocky outcrop. The broken line crossing the image ( $\mathrm{SW}$ to NE) corresponds to the road connecting Hombori to Gossi. (b) Massi, "red" pond slightly turbid water with aquatic vegetation (center of the pond). A-B= rocky outcrop, B-C=vegetation, $\mathrm{C}-\mathrm{D}=$ free water, $\mathrm{D}-\mathrm{E}=$ water covered with aquatic vegetation, $\mathrm{E}-\mathrm{F}=$ rocky outcrop.

NDVI, Green and NDTI) in the centre of the pond and adding a tolerance to the result to obtain the thresholds above/below which a pixel was classified as "pond".

\subsection{Classification of LANDSAT images}

LANDSAT images have the advantage of a wide ground coverage (Figs. 2 and 3), as well as a good spectral resolution, especially for TM and ETM images with two channels in the middle infrared wavelengths, which are very useful to detect water bodies. A supervised classification scheme was applied to TM and ETM series for September and November to obtain a regional evaluation of the areas covered with water.

In order to compare the area flooded in the seventies and the eighties with more recent years, a supervised classification was also performed on the MSS scenes of 1972, 1975, and 1984. Following Liebe et al. (2005), up to nine types of flooded surfaces were identified, depending on the turbidity of the water and the presence or absence of aquatic herbs, or woody plants. Theses types were classified separately and then gathered into either turbid or clear waters. Temporary and superficially flooded plains on fine textured soil, with or without tree and vegetation cover were also classified and kept separated from ponds. Clouds and clouds shadows were manually masked.

\subsection{Classification of MODIS images}

Given the coarse spatial resolution $(250 \mathrm{~m})$ and the spectral resolution of MODIS images, (red and infrared channel only for this resolution), small ponds and "red" ponds are not monitored. In addition, since a pixel surface is equivalent to almost 7 ha, a classification based on pure pixels only may lead to a rough approximation of the effective pond's surface for most ponds in the Gourma. Therefore, it was necessary to consider a sub-pixel classification to refine the result. The algorithm, which has been designed, consists first in defining a region of pure open water pixels and one of "dry" pixels (which can either be rainfed vegetation, or bare soils, or rock outcrops) surrounding the pond to be outlined. For each of these two regions, spatially averaged values are computed for both original channels (red and infrared) and NDVI values. All pixels with a NDVI value lower than the average of the "pure water" region are classified as "flooded pond". Conversely, pixels with NDVI values higher than average over "dry soil" are classified as "dry soil". The pixels with NDVI in between are considered mixed pixel. The fraction of open water is assessed by the following linear un-mixing relationship:

$\mathrm{NDVI}_{\text {mixed }}=k \cdot \mathrm{NDVI}_{\mathrm{dry}}+(1-k) \cdot \mathrm{NDVI}_{\mathrm{water}}$

where $k$ is a linearity coefficient $(0<k<1)$. The proportion 
of water in a mixed pixel is given by $(1-k)$. This proportion is computed for all mixed pixels and summed to the pure open water pixels to assess the total pond area.

\subsection{Classification of panchromatic images}

Panchromatic images include aerial photographs as well as CORONA images, acquired in a mono-spectral mode. This prevents automatic detection of water bodies, which may be confused with rock outcrops or bare sands (Leblanc et al., 2008). Ponds were therefore outlined manually by an operator, based on field experience and based on the comparison with the reflectance of the surroundings (texture, glint). As the result might be operator dependant, the delimitation process was made by different persons.

\subsection{Assessments of the classifications}

For most high spatial resolution images (CORONA, aerial pictures, FORMOSAT, SPOT and LANDSAT-MSS), the assessment of the classification is done visually, by overlapping the classified pond's contour with the corresponding image. For LANDSAT TM and ETM, images, the accuracy of the maximum likelihood classifier is evaluated by comparing classified data with an independent set of soil, land use and vegetation cover maps resulting from field studies (Hiernaux, unpublished). These classifications proved to be quite precise, with an overall accuracy ranging from $97 \%$ to $99 \%$, depending on the images. An example of the accuracy assessment is reported in Table 3 .

These evaluations are not possible in the case of MODIS images, for which a 200-ha water body contains few pure pixels (10-30, depending on the shape of the pond) and several mixed pixels that make the contour difficult to identify visually. Thus, surface variations computed from MODIS images have been compared to the results from high spatial resolution images, namely the FORMOSAT and SPOT times series in 2005, 2006 and 2007. The main outcomes are presented in Fig. 5. During the rainy season, the variation of the flooded area derived from MODIS compare well with the area assessed with the other sensors, with a difference of less than $10 \%$.

The agreement is weaker at the end of the dry season, with a relative difference reaching up to $78 \%$ in the worst cases. This is explained by the sharp decline of the number of "pure water" pixels as the pond dries up. For most ponds, the classifications at the end of the dry season are thus based on mixed pixels and are therefore less accurate. Moreover, some ponds, like Ebang Mallam, split into several small ponds, which size may be smaller than the spatial resolution of MODIS. This is in line with previous studies using moderate and low resolution sensors (Verdin et al., 1996; Gond et al., 2004; Haas et al., 2009), which concluded that surface estimation is accurate above a given threshold of
Table 3. Confusion matrix and accuracy estimators for the classification of a whole LANDSAT-ETM image with a maximum likelihood classifier (image collected on 29 October 1999).

\begin{tabular}{lcccc}
\hline Class label & Commission & Omission & $\begin{array}{c}\text { Producer } \\
\text { accuracy } \\
(\%)\end{array}$ & $\begin{array}{c}\text { User } \\
\text { accuracy } \\
(\%)\end{array}$ \\
\hline Blue ponds & 0.00 & 3.99 & 96.01 & 100.00 \\
Red ponds & 0.00 & 1.76 & 98.24 & 100.00 \\
Overall accuracy: $97.16 \%$ & & & \\
Kappa coefficient: 0.94 & & & \\
\hline
\end{tabular}

a few ha or tens of ha, allowing pure pixels to be present. Ponds' size at the end of the wet season, typically from September to November, is therefore preferred to carry out the analysis of the long term changes of the flood in ponds.

\section{Results}

\subsection{Seasonal variability}

Rainfalls over the Gourma depend on the West African Monsoon, with rains usually starting in June and ending in late September, sometimes not until October (Frappart et al., 2009). The flood regime of the ponds is closely related to the rainfall distribution and its spatial and inter-annual variability. The monitoring of the seasonal cycle of Agoufou and Ebang Mallam with eight year of MODIS data shows that two phases can be distinguished (Fig. 6):

1. The rising up of the flood fed by surface runoff. There is an abrupt rise of the pond area generally occurring between June and July followed by marginal changes during the rest of the rainy season (August and September).

2. The decrease of pond's area, which is mostly due to evaporation, with some infiltration and, to a lesser extent to the use by human for drinking, irrigation and livestock watering (Desconnets, 1994). Most ponds in the Gourma dry up between November and May.

\subsection{Inter-annual variability}

The flooded surface of ponds is influenced by the interannual variability of rainfall, both in volume and intensity of the rain events (i.e. rainfall deficit, droughts) and in their timings (i.e. delay of the first rains which may occur as late as late July). The variations of the flooded surface of the Agoufou pond inferred from 1999-2007 data (Fig. 7) show a significant relation with precipitations $\left(r^{2}=0.78\right.$ for a linear regression) that only holds over that period. The flooded area in Agoufou reached its maximal size at the end of October 

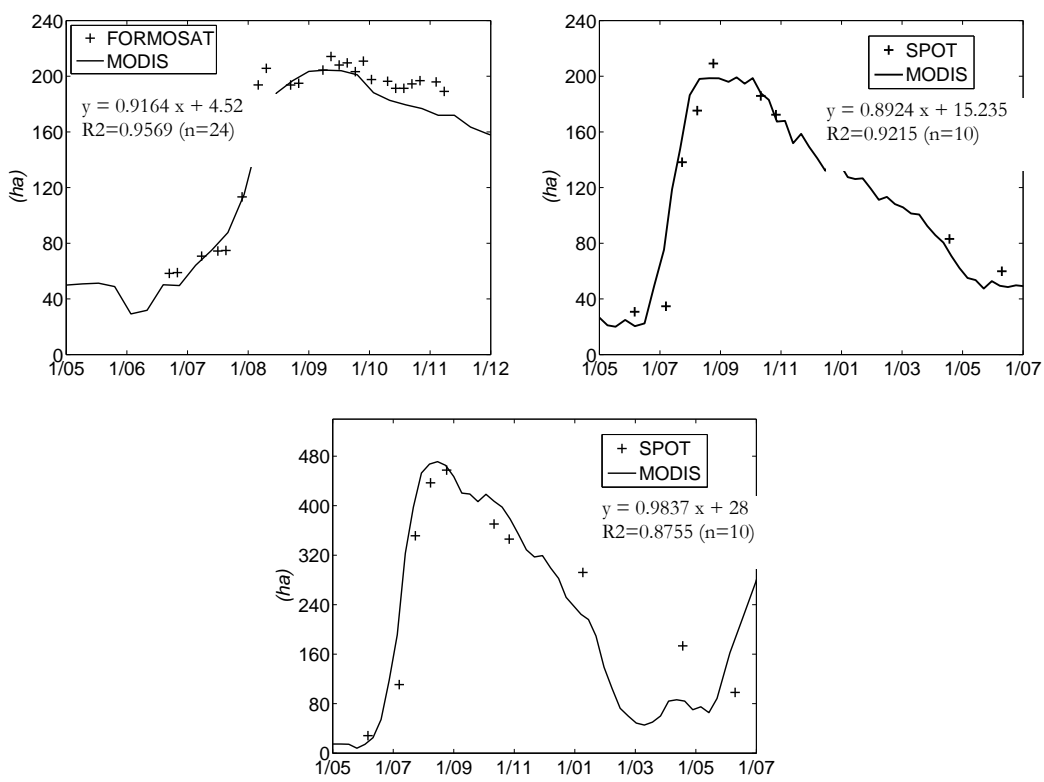

Fig. 5. Comparison of ponds' area derived from MODIS (curves) with area derived from SPOT-HRVIR and FORMOSAT-2 (point). Top is Agoufou, bottom is Ebang Mallam.

1999, which was an unusually wet year for the 1980-2000 period (Fig. 1), whereas it was minimum in 2004, a year characterized by a strong rainfall deficit over the Gourma, close to the major droughts of the 1970' and 1980'. These two years excepted, the values of the flooded surface do not appear to be widely scattered over the last 10 years: for cumulative rainfall ranging from $290 \mathrm{~mm}$ to $400 \mathrm{~mm}$, the surface of Agoufou pond falls between 150 ha and 230 ha (Figs. 6 and 7) and Ebang Mallam falls between 300 ha and 500 ha (Fig. 6).

\subsection{Changes in the flood regime of ponds}

The analysis reported above provides a range of seasonal values of flooded areas for the two ponds of Agoufou and Ebang Mallam. These values are compared to the few punctual estimations of flooded area available for the previous years (isolated points in Fig. 6). The comparison holds for estimations made at the same time of year and for similar rainfall amount. The evolution of the annual maximum of flooded area since the 1950's is remarkable (Figs. 6, 7 and 8). Even when the seasonal and inter-annual variability are taken into account, the area of open water during the wet period, which preceded the drought of the 1970's and 1980's, turns out to be much smaller than the areas reached nowadays (Figs. 6 and 8). For example, the area flooded at Agoufou and Ebang Mallam only reached a few hectares in the sixties and seventies, and both ponds were drying up a couple of months after the last rains. For approximately the same cumulated rainfall value of $375 \mathrm{~mm}$, the size of the water area is much larger nowadays than what it was in 1965 or 1996 (Fig. 7). Likewise, to reach a similar size, Ebang Mallam pond needed twice more rainfalls in 1966 than in 2004. In 1990, the area of these two ponds increased to such an extent that open water remained during the whole dry season. The swelling of these pond flood does not match the onset (early 1970's) nor the peak of the drought (mid 1980's). It did not coincide either with the wetter years of (1991, 1994, 1996 and 1999) but preceded them, starting in the early 1970's and accelerating in the late 1980's. Moreover, the area flooded in both ponds continued to grow after 1990 to reach the present size.

\subsection{A regional phenomenon}

The supervised classification of flooded surface in September 1975, 2001, 2002 and 2007 displays important changes for the 91 ponds located in the overlapping area of the four LANDSAT images covering the centre of the Gourma region (Fig. 3). All together, the flooded area of these ponds reached 13800 ha in 1975, 27157 ha in 2001, 28742 ha in 2002 and 28351 ha in 2007 , thus an overall increase by $105 \%$ over the 1975-2007 period of time (Fig. 9a). The analysis of the time series of November images from 1972, 1984, 1986, 1999, 2002, and 2006, leads to the same conclusions (Fig. 9b). This series documents the evolution of the 51 ponds found in the overlap of the November images (Fig. 3), it samples a smaller region than the September series, but with a higher frequency over time. The images from the 1970's and 1980's show that the change in water area started in the early 1970's and strongly accelerated between 1986 and 1999. This is fairly consistent with the September time series, which displays a strong change between 1975 and 2001, and also with the data collected for Agoufou and Ebang Mallam in 1965, 1966, 1975, 1990 and 1996 (Figs. 6 and 7). 
(a)
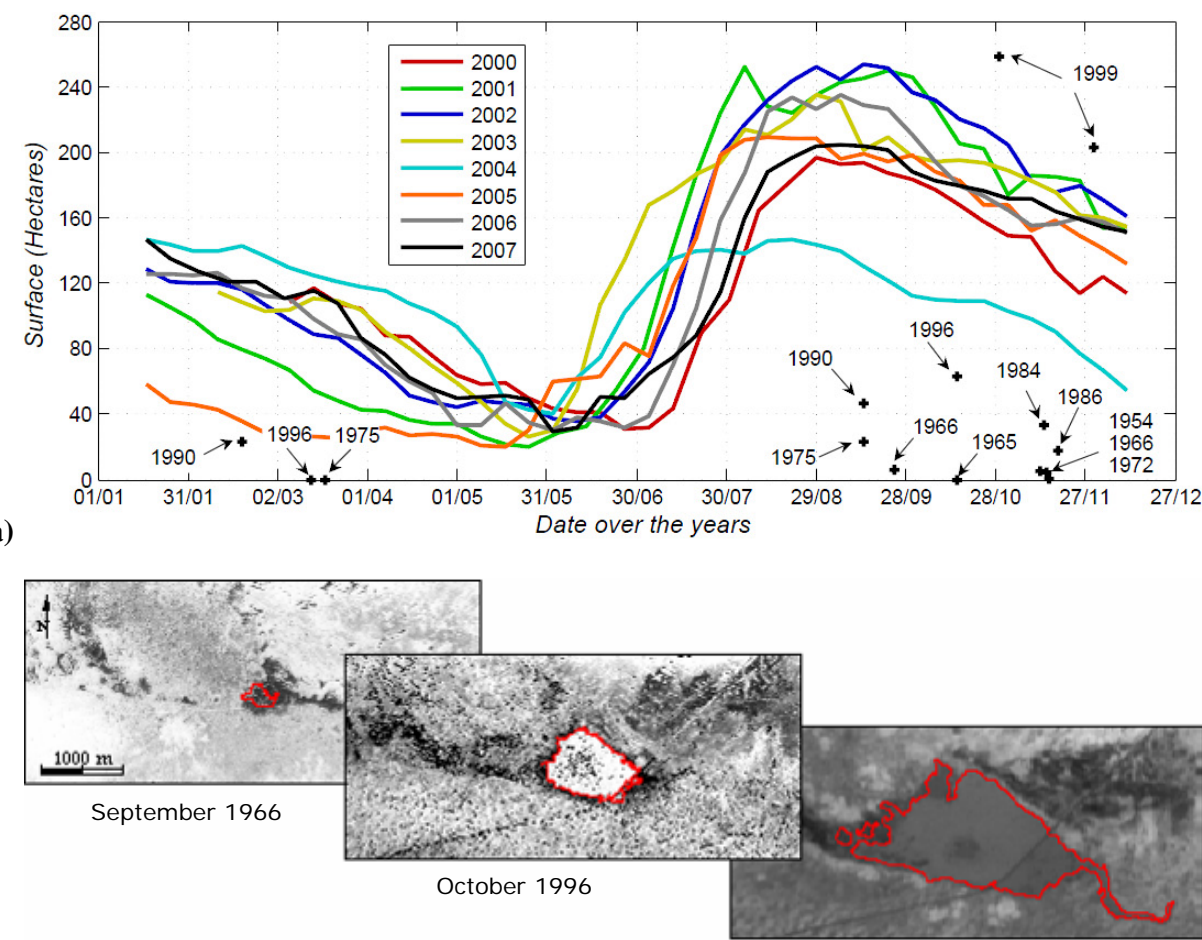

(b)

October 1999

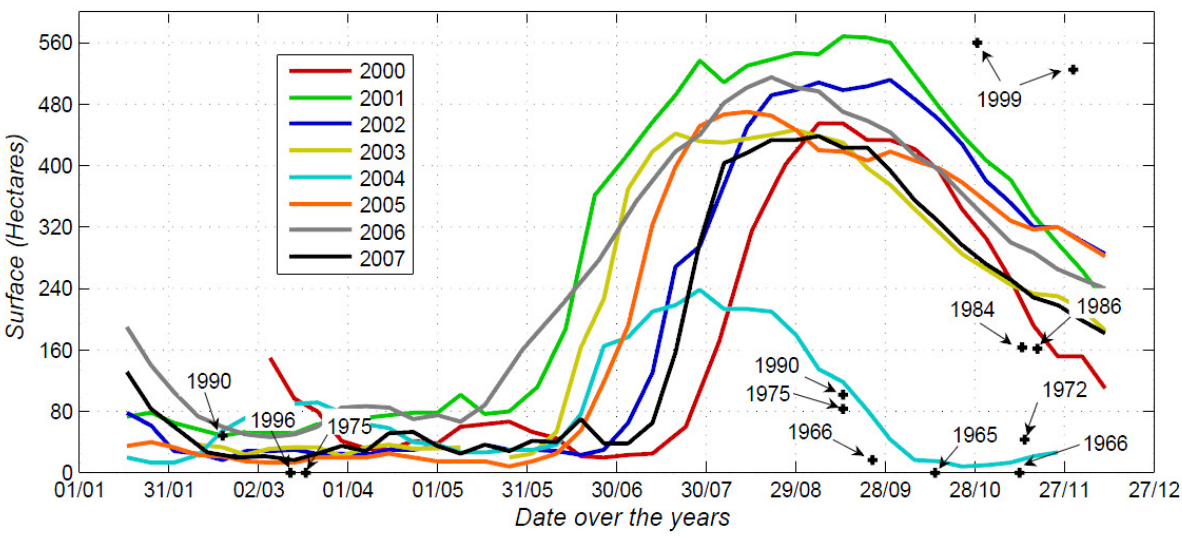

(c)

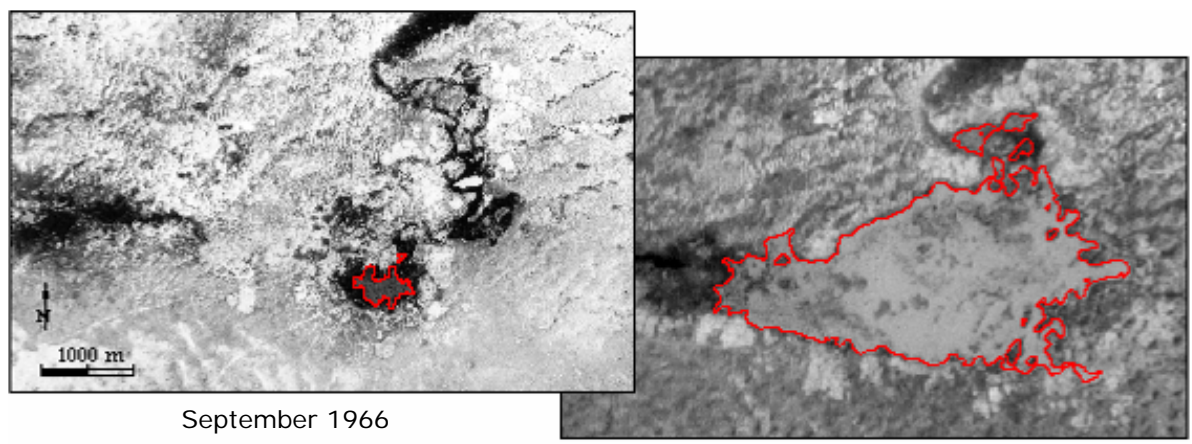

(d)

October 1999

Fig. 6. Variation of the surface of Agoufou (up) and Ebang Mallam (down) over the last 50 years showing a dramatic increase. Curves are derived from MODIS data, while isolated dates come from LANDSAT, SPOT or panchromatic images. The scale is uniform throughout all images. 


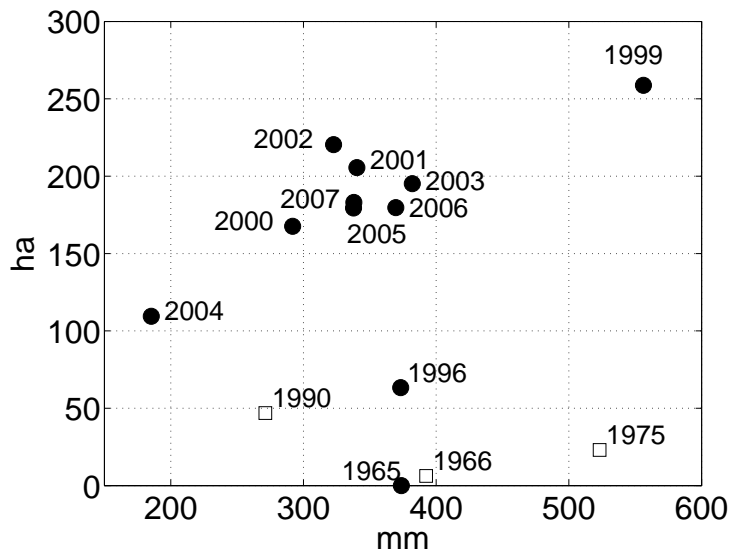

Fig. 7. Pond's area versus annual precipitations for the pond of Agoufou, October data (full circle) and September data (open square).

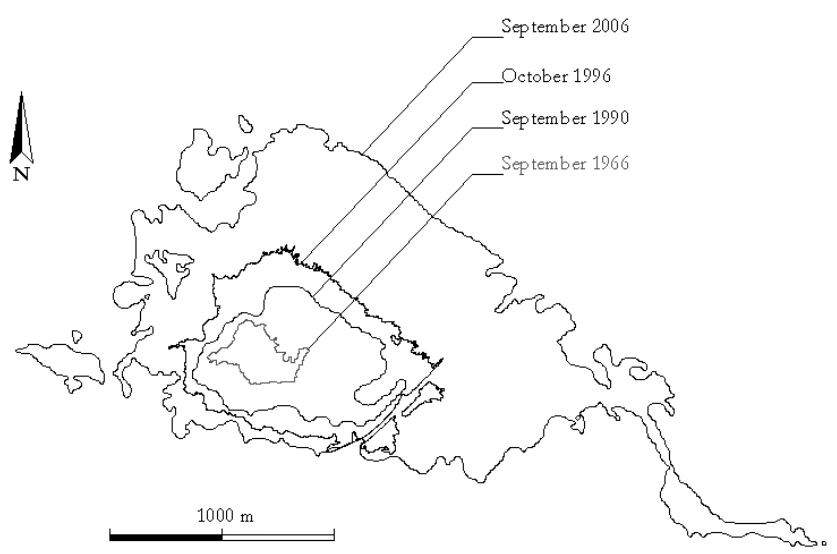

Fig. 8. Successive contours of the pond of Agoufou, between 1966 and 2006, at the end of the rainy season, showing the remarkable increase of the pond.

The spatial distribution of the observed increase has been analyzed for the 2002-1975 paired classifications of September images. The overall $108 \%$ area increase observed during this time interval results of different changes in flood area from each individual ponds as shown in Fig. 10. Indeed, 22 ponds had no flood increase but rather display a slight decrease, 6 increased by less than $50 \%, 14$ by 50 $100 \%$ and 49 by more than $100 \%$. When grouped by large geographic zones: erosion surfaces of northern Gourma, of central Gourma, and southern plains (Fig. 3), it appears that ponds' flood spread at increasing rates from south to north (Fig. 11). Moreover, this expansion in the northern and central regions is mostly caused by the increase of area flooded with turbid waters ("blue" pond), while the area flooded with clear waters ("red" pond) display a lower increase; whereas in the southern plains, the small contribution of turbid waters decreases slightly, while clear water increase by $57 \%$ (Fig. 11).
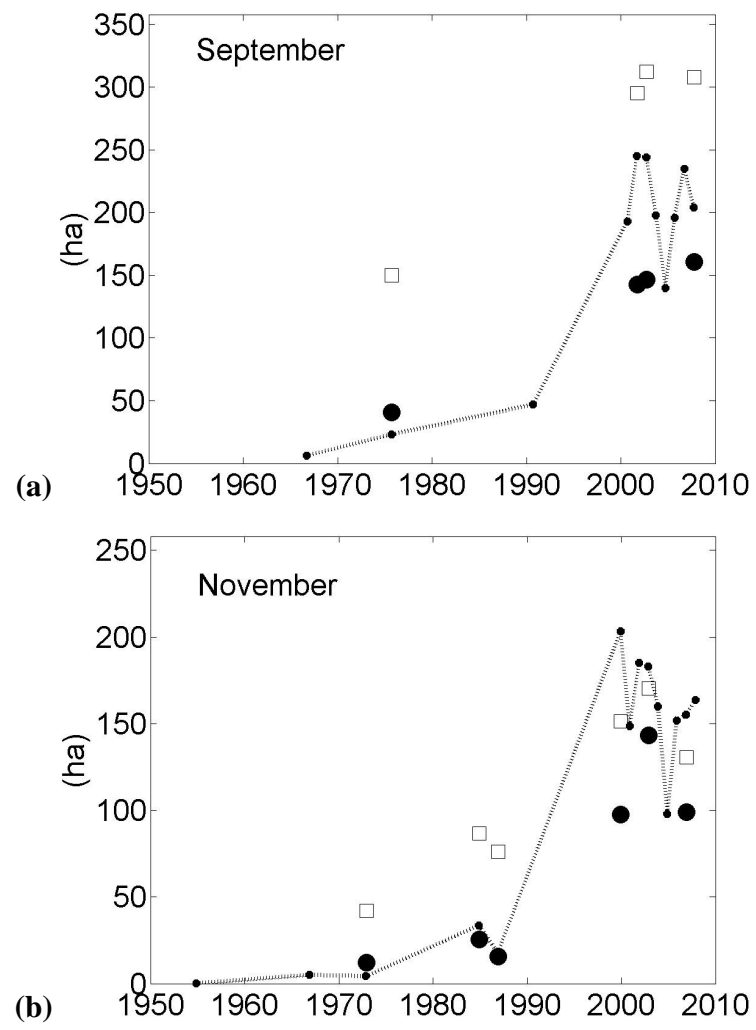

Fig. 9. (a) Average surface of water per pond (open square), average surface of turbid water (full circle) for the 91 ponds present in all September Landsat images. Also figured is the surface of the Agoufou pond in September (line), derived from all data sources. (b) Same as (a) but for November and for the 51 ponds present in all November Landsat images.

The area increase of pond's flood is a regional phenomenon, which displays a continuous spectrum of individual responses (Fig. 10), with both the geographical position and the type of water (turbid/clear associated with the presence of aquatic vegetation) explaining some of the inter-pond variability.

When replaced in this regional context the changes of the flooded area observed at peak flood at Agoufou and Ebang Mallam are large but not exceptional. Indeed, the relative increase rates between September 1975 and 2002 are 980\% and $502 \%$, respectively, thus 9 and 4.6 times larger than the overall rate for the 91 ponds of central Gourma (Fig. 9a). However, these rate values are closer to the mean rate of increase of flooded areas (370\%) calculated for the 31 turbid water ponds found in the central region. Similarly, the changes in flooded areas observed between November 1986 and November 2002 at Agoufou (958\%) and Ebang Mallam (98\%), reach respectively, 6.2 and 0.8 times the relative rate calculated for the 51 ponds (Fig. 9b). Hence, the increase rate of Agoufou compares better with the mean rate for all blue ponds (811\%). while the lower rate of Ebang Mallam is mostly due to an earlier increase in flood. 


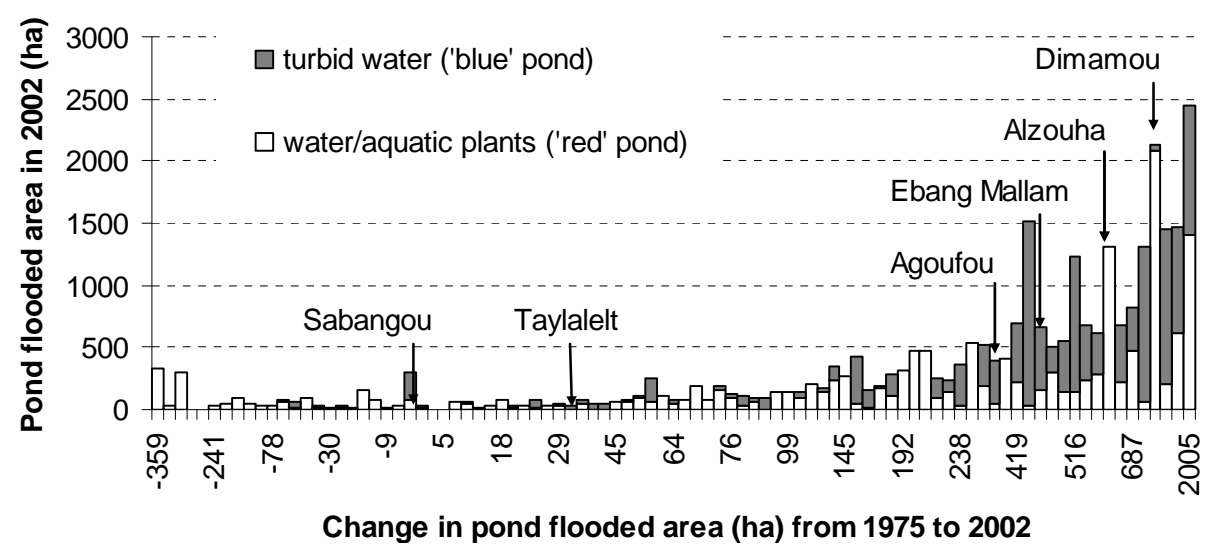

Fig. 10. The 91 ponds of central Gourma ranked by the absolute value of the change in flood area between 1975 and 2002 (x-axis, negative values indicate decrease in flood area, positive value increase), in relation with the area covered by the pond in 2002, separated into turbid water without vegetation ("blue" pond) and less turbid with aquatic vegetation ("red"pond).

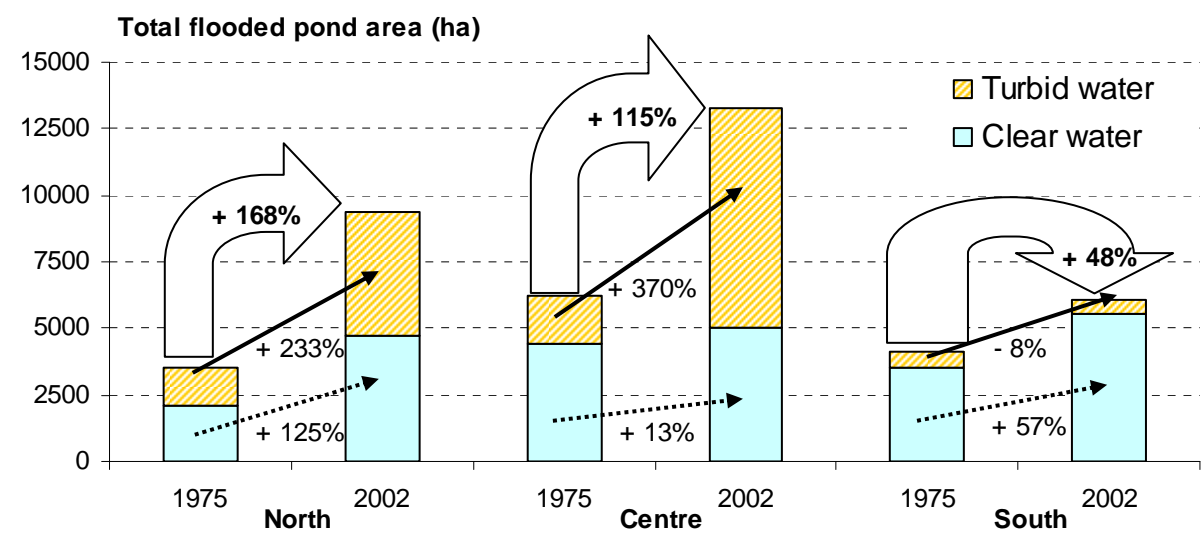

Fig. 11. Change in areas flooded with clear or turbid water (91 ponds in total) observed between 14 September 1975 and 3 September 2002 in the Gourma. Relative rates of change are calculated for the overall flood and for both clear and turbid water. Ponds are grouped following their location in the Gourma (see map in Fig. 2).

\section{Discussion}

\subsection{Technical considerations}

The large time span over which ponds were monitored brought the main challenge of this study. It required the combination of information from aerial photos and satellite images coming from a wide variety of sensors. The objective was to obtain coherent temporal information on the flooded areas of ponds in spite of the different quality, and the different spectral, temporal and spatial resolutions of those data. High spatial resolution images, such as SPOT or LANDSAT, as well as FORMOSAT (but lacking middle infrared channel), provide accurate assessment of the flooded area of ponds, and thus trends of theses flooded areas over time. Panchromatic photos or images do not allow automatic detection of water bodies and hence photo-interpretation has been used to calculate flooded areas. In the Gourma region, the observed changes over time were so large that these methods were accurate enough. When using coarse resolution images (MODIS), a threshold for accurate assessment of pond's flood was determined. The algorithm developed to include mixed pixels proved less satisfactory when the area flooded gets inferior to 25 ha, but was accurate enough for larger water bodies (Fig. 5). Overall, the magnitude of the error made on the assessment of the flooded area of ponds, at least for the "blue" ponds, is small compared to the large increase observed for these ponds between the 1950's and present time.

\subsection{A paradoxical and uneven dynamics}

The expansion of pond's flooded area between 1975 and 2002 is a regional phenomenon, but it is uneven. It is mostly due to an increase of the area covered by turbid water $(260 \%)$ while the increase area of clear water is less important $(51 \%)$. The average increase is also larger in the 
centre and to the north of the Gourma than in the South, and more specifically in the depression that surround the Hombori mounts. Yet, there are individual ponds in the centre and north whose flooded areas have not increased much, and reciprocally, there are a few ponds in the south that have largely increased. These remote sensing outputs are also confirmed by field observations: the death of woody plants in the deepest part of the pond following the anaerobic conditions due to a prolongation of the flood period was only observed in "blue" ponds; no change was observed either, on the shore line, nor on the topographic profile of the red ponds. The radiometric signature of the ponds is associated with both water turbidity and the presence of aquatic plants, which development is impeded by high turbidity. High turbidity in turn depends on the geological nature of the watershed, schist producing more loam and clay alluvium than do sandstone and hard pan, and on the speed and the duration of the runoff flow. Some of the discrepancies in the flood change over years observed between "blue" and "red" ponds presumably arise from these differences. In addition, it is expected that rainfall variability causes inter-annual variability in flooded areas of ponds, but this should vanish at decadal time scale (Frappart et al., 2009). A more persistent cause of variability in the observed changes may be related to changes in connectivity of the runoff web. Indeed, structural modifications of the runoff system have been observed. Increasingly concentrated runoff accelerated water flows with the web of rills expanding upstream, while it deepened and broadened the gullies downstream. Enhanced flow momentum, in turn, shortcuts some of the relay ponds, connecting or reinforcing existing connections between watersheds. This applies to Agoufou, which effective watershed in 1975 only extended over $32 \mathrm{~km}^{2}$. In 1986, it had expanded to $127 \mathrm{~km}^{2}$ by connection of the watershed that was previously only feeding the Taylalelt ponds. It had expanded again by $41 \mathrm{~km}^{2}$ in 2001 with the connection established to the west with the watershed that so far was only feeding the Sabangou ponds. However, such a change in watersheds connectivity does not explain the large area increase of the Agoufou pond, since the sum of all ponds in the total watershed (Agoufou + Taylalelt + Sabangou) exhibits a large increase (Fig. 10). A change in watershed connectivity is part of the phenomenon affecting the flood regime of ponds in the Gourma region and each watershed has its own dynamics, regarding how connections can evolve depending on its topography and geomorphological traits.

\subsection{What are the possible causes of the uneven increase in pond flooded areas?}

In the Gourma region, increase in rainfall amount (Fig. 1) as well as increase in daily rainfall intensity can be ruled out as a direct cause. Indeed, Frappart et al. (2009) did not find any trend in rain per rainy day over 1950-2000. They found, however, a possible trend towards more intense rains (rain per rainy day) in 2000-2007 compared to the previous decades. Yet, this possible increase occurred well after pond's increase in flooded area (starting in the early 1970' and acceleration in the late 1980'). Unfortunately, more precise analysis of rainfall intensity based the high frequency records are only available for more recent years, since the deployment of automatic rain gauges under the AMMA project.

Increase of flooded areas of ponds might also be caused by sediments deposition. Sediment deposition in Gourma ponds certainly increased during the study period with increasing runoff and soil erosion but it should play a minor role in the flood area expansion of the major ponds because of the long time required for coarse alluvium to reach the outlet pond in this overall flat landscape.

Increased surface runoff is therefore the most plausible factor causing the observed increase of the pond flooded areas in Gourma. This is in line with the increased runoff observed in other Sahelian regions (Mahé et al., 2003, 2005a, b; Descroix et al., 2009). However, the unevenness of the increase in flooded areas would then be explained by the unevenness of the increase in soil surface runoff depending on whether the watershed is feeding "blue" or "red" ponds. Red ponds concentrate in the southern part of the Gourma region, especially the watershed spreading from the sandstone plateaux of Hombori, but there are also some red ponds in central and northern Gourma, including large ones such as Dimamou, Doro and Karouassa (Fig. 2), which watershed have substantial schist substrate. Yet the fact that a number of the "red" ponds are located along a stream could explain their behaviour even under the hypothesis of increased runoff. Indeed, increased run-on could be evacuated as a downstream discharge or could be absorbed in the swelling of the surrounding flood plains without marked effect on the flood level and thus the flooded area of the pond. This expansion of flood in alluvial plains could in turn explain the expanding woody plant population at the edges of the low land open forest observed since the mid 1980's in most low land clay soil in Gourma plains (Hiernaux et al., 2009a). The contrasted flood dynamics between "blue" and "red" ponds would thus not imply local differences in runoff increase from rocky and shallow soils slopes but differences in the fate of runoff water between storing in ponds, temporal accumulation in flood plain, or rapid infiltration over sandy soils as observed in western Niger (Favreau et al., 2009).

\subsection{What are the possible causes of the increase in surface runoff?}

It is noteworthy that the "blue" ponds, especially those which increased most since the 1980's, are not located in the area where crops concentrate. In addition, most ponds in the depression that surrounds the Hombori mounts, area under strong anthropogenic pressure, are of "red" type and have not increased size much. As a consequence, nor the limited increase in area cropped, nor the intensity of grazing 
and trampling by livestock maintained longer, and in higher numbers, at the vicinity of settlements, can be advocated as leading factor of the increased runoff, as suggested for other regions of the Sahel such as in South-West Niger (Leblanc et al., 2008; Favreau et al., 2009). Indeed, crop fields (less than $3 \%$ of total land area) are confined to sandy soils that only marginally contribute to runoff. In addition to crops expansion, degradation of vegetation cover may also be caused by wood harvesting to meet the needs of local population for domestic use. During the most severe years of the droughts (1972-1973 and 1983-1984), some people ended in harvesting and selling wood to buy millet in order to face the deficiency of their own millet crops. But again, the Gourma region does not seem to be concerned by the aspect of human deforestation. Benjaminsen (1996) studied the evolution of woody population over the Malian Gourma, between 1955 and 1985, and came to the conclusion that the significant decrease in the number of trees in this area is only due to the drop in rainfalls, and that the domestic use of firewood could not be involved. Since then, the monitoring of woody plant populations from 1984 to present in the Gourma concludes to an overall increase both in density and cover of the woody population (Hiernaux et al., 2009a). There are however important exceptions to this trend: the woody population located on shallow soils, over rock or hard pan outcrops, have experienced a continuous decline in density and cover, associated to a profound change in structure (Fig. 12 and Hiernaux et al., 2009a). For example, the "tiger bush" arrangement common on the hard pans of southern Sahel with dense thicket set perpendicular to the slope, have been decimated or dismantled (Roussel, 2009), and in this case replaced by totally different arrangements in which scattered shrubs settled along the rills and thus along the slopes. The rock outcrops, and associated shallow soils, extend on a third of the Gourma territory (Mougin et al., 2009), and they constitute the landscape units generating most of the runoff. In contrast, the woody populations of the two other main types of landscape units, the sandy soils of dunes and valleys (55\%) and the loamy clay soils of lowlands (12\%) progressively regenerated after the losses due to the drought (Fig. 12). Moreover, the herbaceous vegetation on sandy soils and on lowland clay soils monitored in Gourma revealed very resilient to droughts, with a fast reclamation of the production, within $2-5$ years as observed in field surveys (see Fig. 5 in Hiernaux et al., 2009b) and by remote sensing (Tracol et al., 2006). On rock slopes and associated shallow soils, herbaceous layer only recovered partially since mid 1990's in scattered patches set along the drainage lines and on thin sand depositions, offering little resistance to runoff. The persistent decline of herbaceous and woody vegetation cover on these rock outcrops and shallow soil has been monitored in the field, but is hardly quantifiable by remote sensing due to leaf area indexes reaching at most a few percents and to the extremely patchy distribution. Whether a future return to normal precipitation in the next decades could cause a reversal of flood size and

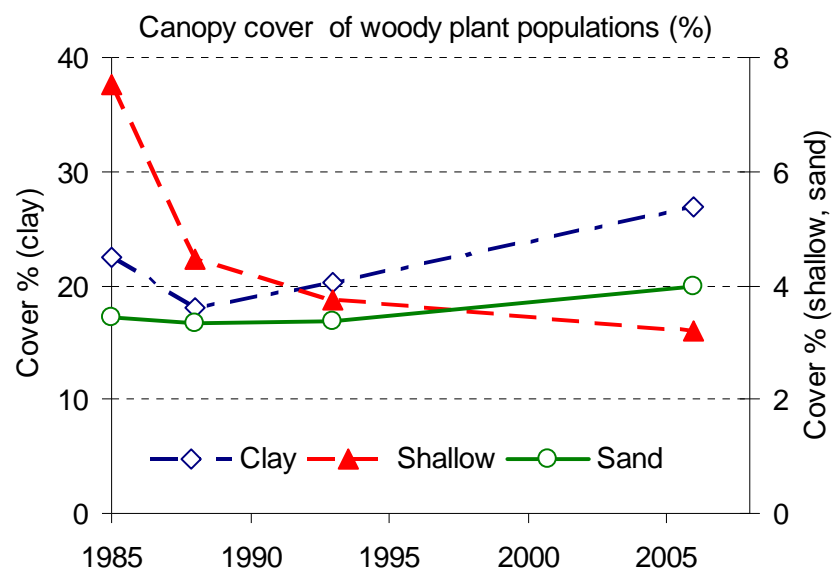

Fig. 12. Changes of the mean the canopy cover of woody populations over low-land clay soils ( 5 sites, left scale), dunes and lowland sandy soils (13 sites, right-scale) and eroded slopes shallow soils (4 sites, right scale) in the Gourma following the 1983-1984 drought (adapted from Hiernaux et al., 2009a).

regime in ponds, triggered by a recovering of vegetation on the shallow soil, is an important question for pastoral Sahel, which deserves dedicated monitoring.

\section{Conclusions}

Changes in the flooded area of ponds in the Gourma region were established through the use of multi-date and multisensor satellite images. The actual classification process to outline the flood area of ponds has to be adapted to fit each type of spectral resolution (lack or presence of a middle infrared band, panchromatic image) and spatial resolution (for a resolution coarser than $30-\mathrm{m}$ mixed pixels had to be accounted for).

The outcomes enabled to document the seasonal dynamics of flooded area in ponds with the fast rising of the flood related to rainfall distribution followed by a slow retreat of the flood during the dry season for a majority of the ponds in the Gourma region. The year to year changes of the maximum area flooded was quantified for two ponds (Agoufou and Ebang Mallam) that experienced a spectacular increase in flood level and duration, evolving from temporary to permanent ponds. Indeed, for a same total rainfall of $380 \mathrm{~mm}$ at the end of October, the size of the pond of Agoufou has been multiplied threefold between 1996 and 2003. The flood evolution of these two ponds is at the larger end of the general behaviour of Gourma ponds, but it is typical of turbid ponds of the central zone. The results of this study showed an overall trend of flood increase from the 1950's till present causing the flooded area of ponds observed at the peak of the flood to double from 1975 to 2002.

The causes of the changes in flood regime of ponds were analysed in relation to their geographic location, the soil and 
land use particularities of their watershed and the radiometric characteristics of their flood. The possible impact of cropland expansion, limited in this region, and intensification of forestry and pastoral use were discussed and considered secondary. Instead, it is argued that the lasting impact of the climatic droughts of the 1970's and 1980's on the herbaceous and woody plant vegetation over the shallow soils on rock and hard pan outcrops, and its consequences on the runoff system and the routing of the waters flows, are the main causes of this spectacular phenomenon.

Acknowledgements. The authors thank Eric Mougin, Niall Hanan and two anonymous reviewers for stimulating discussions. They thank Olivier Hagole for his help in providing satellite data (FORMOSAT) with the adapted corrections and Valérie Trichon for providing the 1996 aerial photos. The authors are grateful to the Institut d'Economie Rurale (IER) and the Direction Nationale de la Météorologie (DNM) for the collaboration in field data collection, and to the Institut de Recherche pour le Développement (IRD) Representation in Mali for all logistical support. Based on a French initiative, AMMA was built by an international scientific group and is currently funded by a large number of agencies, especially from France, the UK, the USA and Africa. It has been the beneficiary of a major financial contribution from the European Community's Sixth Framework Research Programme.

Edited by: B. Schaefli

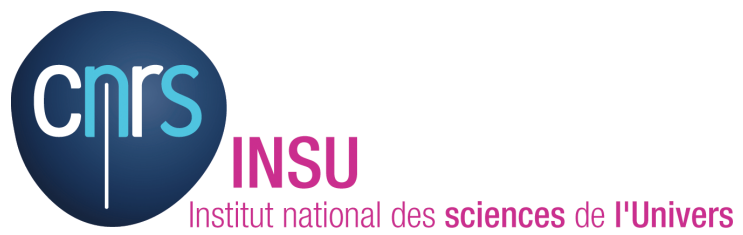

The publication of this article is financed by CNRS-INSU.

\section{References}

Ag Mahmoud, M.: Le haut Gourma Central, 2nd edn., edited by: Le Floc'h, R., CEFE/CNRS, Montpellier, 133 pp., 1992.

Benjaminsen, T. A.: Bois-énergie, déboisement et sécheresse au Sahel: le cas du Gourma malien, Sécheresse, 7, 179-185, 1996.

Boudet, G.: Désertification ou remontée biologique au Sahel, Cahiers ORSTOM, Série Biologie, 12, 293-300, 1977.

Boudet, G., Cortin, A., and Macher, H.: Esquisse pastorale et esquisse de la transhumance de la région du Gourma (Mali), DIWI, Essen, Germany, 120 pp., 1971.

Boudouresque, E.: La végétation aquatique du Liptako (République du Niger), thesis, Univ. Paris XI, Orsay, France, 391 pp., 1995.

Bourn, D. and Wint, F.: Wet season distribution and abundance of livestock populations and human habitants in the Gourma region of Mali, Resource Inventory and Management, St Hellier, Jersey, UK, 53 pp., 1985.

Cheula, A.: Dynamique de l'occupation des sols en milieu sahélien. Espaces cultivés et couverture ligneuse dans la commune de Hombori, Mali. Mem.Master2 Télédétection et Géomatique Appliquées à l'Environnement, Univ. Paris Diderot, 44 pp., 2009.
d'Herbès J.M., Valentin C., Thièry J.: La brousse tigrée au Niger: synthèse des connaissances acquises. Hypothèses sur la genèse et les facteurs déterminants les différentes structures contractées, in: Fonctionnement et gestion des écosystèmes forestiers contractés sahéliens, d'Herbès, edited by: Ambouta, J. M. K. and Peltier, R., John Libbey Eurotext, Paris, 131-152, 1997.

Défossez, M.: Contributions à l'étude géologique et hydrogéologique de la boucle du Niger, Mémoire BRGM 13, Paris, 174 pp., 1962.

Desconnets, J.-C.: Typologie et caracterisation hydrologique des systèmes endoréiques en milieu Sahélien (Niger-degré carré de Niamey), thesis, Univ. Montpellier II, France, 326 pp., 1994.

Descroix, L., Mahé, G., Lebel, T., Favreau, G., Galle, S., Gautier, E., Olivry, J. C., Albergel, J., Amogu, O., Cappelaere, B., Dessouassi, R., Diedhiou, A., Le Breton, E., Mamadou, I., and Sighomnou, D.: Spatio-temporal variability of hydrological regimes around the boundaries between Sahelian and Sudanian areas of West Africa: a synthesis, J. Hydrol., 375(1-2), 90-102, doi:10.1016/j.jhydrol.2008.12.012, 2009.

Dregne, H. E. and Chou, N. T.: Global desertification: dimensions and costs, in: Degradation and restoration of arid lands, edited by: Dregne, H. E., Texas Tech Univ., Lubbock, Texas, 249-282, 1992.

Favreau, G., Cappelaere, B., Massuel, S., Leblanc, M., Boucher, M., Boulain, N., and Leduc C.,: Land clearing, climate variability, and water resources increase in semiarid south-west Niger, Africa: a review, Water Resour. Res., 45, W00A16, doi:10.1029/2007WR006785, 2009.

Frappart, F., Hiernaux, P., Guichard, F., Mougin, E., Kergoat, L., Arjounin, M., Lavenu, F., Koité, M., Paturel, J.E., and Lebel, T.: Rainfall regime across the Sahel band in the Gourma region, Mali, J. Hydrol., 375(1-2), 128-142, doi:10.1016/j.jhydrol.2009.03.007, 2009.

Gond, V., Bartholome, E., Ouattara, F., Nonguierma, A., and Bado, L.: Surveillance et cartographie des plans d'eau et des zones humides et inondables en régions arides avec l'instrument VEGETATION embarqué sur SPOT4, Int. J. Remote Sens., 25(5), 9871004, 2004.

Haas, E. M., Bartholomé, E., and Combal, B.: Time series analysis of optical remote sensing data for the mapping of temporary surface water bodies in sub-Saharan western Africa, J. Hydrol., 370(1-4), 52-63, doi:10.1016/j.jhydrol.2009.02.052, 2009.

Hiernaux, P.: The crisis of sahelian pastoralism: ecological or economic? Overseas Development Institute, London, Pastoral Development Network, 39a, 20 pp., 1996.

Hiernaux, P., Diarra, L., Trichon, V., Mougin, E., Soumaguel, N., and Baup, F.: Woody plant population dynamics in response to climate changes from 1984 to 2006 in Sahel (Gourma, Mali), J. Hydrol., 375(1-2), 103-113, doi:10.1016/j.jhydrol.2009.01.043, 2009a.

Hiernaux, P., Mougin, E., Diarra, L., Soumaguel, N., Lavenu, F., Tracol, Y., and Diawara, M.: Sahelian Rangeland response to changes in rainfall over two decades in the Gourma, Mali, J. Hydrol., 375(1-2), 114-127, doi:10.1016/j.jhydrol.2008.11.005, 2009b.

Hiernaux, P. and Gérard, B.: The influence of vegetation pattern on the productivity, diversity and stability of vegetation: the case of the 'brousse tigrée' in the Sahel, Acta Oecol., 20(4), 147-158, 1999. 
Lacaux, J. P., Tourre, Y. M., Vignolles, C., Ndione, J. A., and Lafaye, M.: Classification of ponds from high-spatial resolution remote sensing: Application to Rift Valley Fever epidemics in Senegal, Remote Sens. Environ., 106, 66-74, 2007.

Leblanc, M., Favreau, G., Massuel, S., Tweed, S., Loireau, M., and Cappelaere, B.: Land clearance and hydrological change in the Sahel: SW Niger, Global Planet. Change, 61(4), 135-150, 2008.

Leduc, C., Favreau, G., and Shroeter, P.,: Long term rise in a Sahelian water-table: the Continental Terminal in South-West Niger, J. Hydrol., 243, 43-54, 2001.

Leprun, J. C.: Etude de quelques brousses tigrées sahéliennes :structure, dynamique, écologie: in L'aridité une contrainte au développement, edited by: Le Floc'h, E., Grouzis, M., Cornet, A., and Bille, J. C., Orstom Editions, Paris, 221-244, 1992.

Liebe, J., van de Giesen, N., and Andreini, M.: Estimation of small reservoir storage capacities in a semi-arid environment. A case study in the Upper East region of Ghana, Phys. Chem. Earth, 30, 448-454, 2005

Mahé, G., Leduc, C., Amani, A., Paturel, J. E., Girard, S., Servat, E., and Dezetter, A.: Augmentation du ruissellement de surface en région soudano-sahélienne et impact sur les resources en eau, in: Hydrology of Mediterranean and Semiarid regions, edited by: Servat, E., Najem, W., Leduc, C., and Shakeel, A., Proc. Conf., Montpellier, France, 003, IAHS Pub., 278, 215-222, 2003.

Mahé, G., Olivry, J. C., and Servat, E.: Sensibilité des cours d'eau ouest africains aux changements climatiques et environnementaux : extrêmes et paradoxes, in; Regional hydrological impacts of climatic change - hydroclimatic variability, Proceedings of symposium S6 held during the seventh IAHS scientific Assembly at Foz de Iguaçu, Brazil, April 2005, IAHS pub., 296, 169-177, 2005a.

Mahé, G., Paturel, J. E., Servat, E., Conway, D., and Dezetter, A.: The impact of land use on soil water holding capacity and river flow modelling in the Nakambe River, Burkina Faso, J. Hydrol., 300, 33-43, 2005b.
Marie, J. and Marie, J.: La région de Hombori, Essais de géographie régionale en zone sahélienne, Mém. Maitrise, Inst. Géographie, Univ. Rouen, France, 300 pp., 1974.

Mougin, E., Hiernaux, P., Kergoat, L., Grippa, M., de Rosnay, P., Timouk, F., Le Dantec, V., Demarez, V., Lavenu, F., Arjounin, M., Lebel, T., Soumaguel, N., Ceschia, E., Mougenot, B., Baup, F., Frappart, F., Frison, P. L., Gardelle, J., Gruhier, C., Jarlan, L., Mangiarotti, S., Sanou, B., Tracol, Y., Guichard, F., Trichon, V., Diarra, L., Soumaré, A., Koité, M., Dembélé, F., Lloyd, C., Hanan, N. P., Damesin, C., Delon, C., Serça, D., Galy-Lacaux, C., Seghieri, J., Becerra, S., Dia, H., Gangneron, F., and Mazzega, P.: The AMMA-CATCH observatory site in Mali: relating climatic variations to changes in vegetation, surface hydrology, fluxes and natural resources, J. Hydrol., 375(12), 14-33, 2009.

Nicholson, S. E.: Climate and environmental change in Africa during the last two centuries, Clim. Res., 14, 123-144, 2001.

Olsson, L.: On the causes of famine: drought, desertification and market failure in the Sudan, Ambio, 22, 395-403, 1993.

Puech, C.: Plans d'eau sahéliens et imagerie SPOT: inventaire et évaluation des capacités d'exploitation, in: Eau, Environnement et Développement, Intern. Coll. Nouakchott, 20-22 mars 1994.

Roussel, L.: Suivi temporal de la couverture ligneuse au Sahel par télédétection à très haute résolution spatiale, Rapport de stage GGAT, Ecolab, Univ. P. Sabatier, Toulouse, 28 pp., 2009.

Tracol, Y., Mougin, E., Jarlan, L., and Hiernaux, P.: Testing a sahelian grassland functioning model against herbage mass measurements, Ecol. Model., 193, 437-446, 2006.

Rouse, J. W., Haas, R. H., Schell, J. A., and Deering, D. W.: Monitoring vegetation systems in the Great Plains with ERTS. Third ERTS Symposium, NASA SP-351 I, 309-317, 1973.

Verdin, J. P.: Remote sensing of ephemeral water bodies in Western Niger, Int. J. Remote Sens., 17, 733-748, 1996. 